\title{
FORMALIZATION OF THE COTTON DRYING PROCESS BASED ON HEAT AND MASS TRANSFER EQUATIONS
}

\author{
YUNUSOVA SAYYORA TOSHKENBOYEVNA ${ }^{1 *}$, HALMATOV DAVRON \\ ABDALIMOVICH ${ }^{2}$, ATAJONOV MUHIDDIN ODILJONOVICH ${ }^{1}$ \\ and HuZanazarov UlugbeK OLIMOVICH ${ }^{2}$ \\ ${ }^{1}$ Department of Information Processing and Control Systems, \\ Tashkent State Technical University, Tashkent, Uzbekistan \\ ${ }^{2}$ Tashkent Institute of Textile and Light Industry, Tashkent, Uzbekistan \\ *Corresponding author: yunusova_sayyora@mail.ru
}

(Received: 17 th April 2020; Accepted: $9^{\text {th }}$ May 2020; Published on-line: $4^{\text {th }}$ July 2020)

\begin{abstract}
The paper deals with the construction of a mathematical model of the cotton drying process, taking into account the thermal and mass transfer properties of raw cotton components. To determine changes in the temperature of the fibre and raw cotton seeds, the application of Fourier's law is proposed. The mathematical dependence of the change on the humidity of the cotton fibre and seeds along the length of the drum is determined. The rational value of the heat agent consumption in the process of drying raw cotton is also determined. Research methods are based on the provisions of modern trends in management theory and identification. Mathematical models are constructed using analytical methods and equations that describe the physical properties of an object. Methods for constructing a mathematical model usually rely on experimental methods, in particular, the method of acceleration curves, and as a result, the mathematical description becomes a priori inaccurate. It is shown that the mathematical model used is quite adequate for the dynamics of a real object, fully describes it, and characterizes it over the entire range of changes. The analysis of the developed mathematical model based on simulation showed the adequacy of the obtained mathematical dependence of the temperature regime of the cotton drying process with the consumption of heat agent.
\end{abstract}

ABSTRAK: Kajian ini membincangkan tentang penciptaan model matematik bagi proses pengeringan kapas, dengan mengambil kira terma dan sifat-sifat pindah jisim komponen kapas mentah. Bagi mendapatkan perubahan suhu fabrik dan biji benih kapas mentah, penggunaan hukum Fourier telah dicadangkan. Kebergantungan matematik pada perubahan kelembapan fabrik kapas dan biji benih sepanjang drum telah diperolehi. Nilai bersesuaian menggunakan ejen haba dalam proses pengeringan kapas kering mentah didapati. Kaedah kajian berdasarkan tren moden dalam teori pengurusan dan pengenalpastian. Model matematik dibina dengan menggunakan kaedah analisis dan persamaan yang menerangkan ciri-ciri fizikal pada objek. Kaedah bagi membina model matematik selalunya bergantung pada kaedah eksperimen, khususnya, kaedah pecutan melengkung, dan hasilnya, penyataan penaakulan matematik menjadi tidak tepat. Model matematik yang digunakan adalah cukup bagi objek dinamik sebenar, dengan penerangan penuh dan perincian ke atas keseluruhan perubahan. Analisis model matematik yang terhasil berdasarkan simulasi, dilihat cukup kebergantungan matematik terhasil melalui proses pengeringan kapas pada aturan suhu dengan ejen haba.

KEYWORDS: raw cotton; mass transfer; fibers; heat exchange; drying drum; process; differential equations; temperature 


\section{INTRODUCTION}

Raw cotton, as an object of drying, refers to capillary porous-colloidal, heterogeneous materials. Its main components are fiber, skin, and seed core. The structure of the fiber refers to capillary-porous materials.

Due to the structure of raw cotton, the removal of moisture from the core is slow and depends on many factors. Depending on the humidity between the skin and the seed core, air layers are formed, the size of which depend on the maturity and humidity of the seeds. With the presence of an air layer, the process of heat and mass exchange between the skin and the seed core changes significantly, due to the formation of additional resistance to the movement of moisture and heat between the components of raw cotton [1].

The intensification of heating of porous materials, in particular the drying of raw cotton, is determined by the laws of heat and substance transfer inside the body (internal heat and mass transfer) and between the surface of the body and the environment (external heat and mass transfer). To properly understand the mechanism of these processes under thermal influence, it is necessary to develop a thermophysical model of raw cotton that describes the heat and mass exchange processes between the components (fiber and seeds) and the thermal agent (heated air).

When exposed to heat, the thermodynamic equilibrium in the material is disturbed, resulting in internal heat and mass transfer processes associated with the transfer of heat and matter (moisture) in the raw cotton components. In this case, the exchange processes can be implemented:

- due to surface heat and mass transfer;

-internal convective heat exchange between raw cotton components according to Newton's law, according to which the flow of heat and matter will be proportional to the difference in temperature and moisture of each component;

- internal convective heat and mass exchange between the material components and the heated air mass (heat agent);

- transfer of heat and moisture as a result of flow movement in the pores of raw cotton;

- transfer of heat and moisture by diffusive phenomena occurring in each component of the material in the air.

When creating a control system for the technological processes of raw cotton processing, it is necessary to use the entire arsenal of modern theory and practice of automatic control and management, and in addition, it is necessary to have information about the behaviour of the technological control object under the influence of control actions. Effective management of processes and industrial facilities is possible when the main characteristic features inherent in the object are presented in the form of a mathematical description [2-4].

The development of a control system for the process of cotton processing that can provide the required quality of management in the conditions of rapid changes in the parameters of processed raw cotton with changes in environmental indicators is an urgent scientific and technical task. The solution to this problem will significantly improve the quality of management of technological process parameters.

To solve this problem, the processing raw cotton is functionally decomposed into subprocesses, the structure of which changes over time depending on such factors as changes 
in the quality requirements of cotton fibre and raw cotton source material, as well as on the operating modes of aggregates, changes in technological regulations, and production situations.

The complexity of mathematical modelling of the technological process is caused by the insufficient level of development of the theory, the presence of a large number of factors that affect the course of the process, the difficulty of assessing the objective relationship between a set of disturbing factors, as well as the non-stationary parameters of the technological object and their weak observability in real time [4,5]. These factors determine the formalization of the processes, taking into account the main parameters that define it.

It is known that the process of cotton processing consists of interrelated sub-processes, the technological parameters of which significantly affect the quality of the produced preproduct-cotton fibre. At the same time, the most important among them is the process of drying raw cotton [6-8].

\section{FINDING SOLUTIONS METHOD}

Based on the analysis of the functioning of the drying drum, the facts of the existence of functional relationships of each parameter with others are revealed and subsets of interrelated parameters are formed based on these features. The subsets obtained in this way are combined into a common set (set) of interrelated parameters and divided into groups of input parameters $U(t)$, output $y(t)$, variable States $x(t)$, and the drying process. The input parameters of the drying process include: raw cotton consumption $G_{c}\left(u_{1}\right)$, fuel consumption $G_{T}\left(u_{2}\right)$, humidity of raw cotton $\mathrm{B}_{c}\left(u_{3}\right)$, air flow- $G_{b}\left(u_{4}\right)$, air temperature- $t_{b}\left(u_{5}\right)$, air humidity- $\mathrm{B}_{b}\left(u_{6}\right)$. The output parameters of the object are: cotton humidity at the outlet of the drum $-\mathrm{B}_{x}\left(y_{1}\right)$, temperature of cotton at the exit of the drum $-t_{x}\left(y_{2}\right)$, output of cotton from the drum- $G_{x}\left(y_{3}\right)$ temperature of the waste heat agent- $t_{0}\left(y_{4}\right)$, and humidity of the selected heat agent- $\mathrm{B}_{0}\left(y_{5}\right)$ output of the selected heat agent- $G_{a}\left(y_{6}\right)$. In this case, the number of variable state parameters selected: dehumidifier in the drum- $\mathrm{K}_{b}\left(x_{1}\right)$ temperature in the drum- $t_{b}\left(x_{2}\right)$, all cotton in the drum- $G_{b}\left(x_{3}\right)$, heat agent temperature- $t_{a}\left(x_{4}\right)$, heat agent consumption- $G_{a}\left(x_{5}\right)$, and humidity of the heat agent- $\mathrm{B}_{a}\left(x_{6}\right)$.

Using the method proposed in this paper [5-9] we will make differential equations of heat and mass transfer processes in each phase of raw cotton.

Select the volume of the material $V$ bounded by the surface $\mathrm{S}$ and denote by $\stackrel{\mu}{J}_{i j}, \mu_{i l}$ and $\tilde{J}_{i 2}$ accordingly, the flow of moisture in the form of liquid (i=1) and steam (i=2) through the surface $\mathrm{S}$, through $-U_{i j}, U_{i l}$ and $U_{i 2}$ corresponding to the moisture content in each component. Changing the moisture content $U_{i j}$ in volume $V$ occurs due to the derivative $\frac{\partial_{i j}}{\partial}$ internal moisture exchange between components according to Newton's law.

According to the law of conservation of mass of a substance a second change in the moisture content of a material in volume $V$ is equal to the amount of liquid entering this volume per unit of time, both due to its inflow through the surface $S$, and due to its receipt from sources [10-14]. 
Find expressions for the vectors $\tilde{J}_{i j}$. For this purpose, we use Fourier's law, according to which the flow vector will be collinear to the gradient of changes in moisture and temperature.

$\tilde{J}_{i k}=-p_{k}\left(a_{m i}{ }^{(k)} \operatorname{grad} U_{k}+\widetilde{a}_{m i}{ }^{(k)} \operatorname{grad} T_{k}\right)$, where $a_{m i}{ }^{(k)}$ and $\widetilde{a}_{m i}{ }^{(k)}$ are the transfer coefficients.

Given all this, the differential equations for the total mass of transport in the fiber-seedair system are presented as

$$
\begin{aligned}
& \rho_{l} \frac{\partial U}{\partial}+c_{12}\left(U_{1}-U_{2}\right)+c_{13}\left(U_{1}-U_{3}\right)+c^{(T)}{ }_{12}\left(T_{1}-T_{2}\right)+c_{13}{ }^{(T)}\left(T_{1}-T_{3}\right)= \\
& \operatorname{div}\left[\rho_{1}\left(a_{m}{ }^{(l)} \operatorname{grad}_{1}+\widetilde{a}_{m}{ }^{\left({ }^{\prime l}\right.} \operatorname{grad} T_{1}\right)\right] ; \\
& \rho_{2} \frac{\partial U_{2}}{\partial}+c_{12}\left(U_{2}-U_{1}\right)+c_{23}\left(U_{2}-U_{3}\right)+c^{(T)}{ }_{12}\left(T_{1}-T_{2}\right)+c_{23}{ }^{(T)}\left(T_{2}-T_{3}\right)= \\
& \operatorname{div}\left[\rho_{2}\left(a_{m}{ }^{(2)} \operatorname{grad}_{2}+\widetilde{a}_{m}{ }^{(2)} \operatorname{grad}_{2}\right)\right] \\
& \rho_{3} \frac{\partial U_{3}}{\partial}+c_{13}\left(U_{3}-U_{1}\right)+c_{23}\left(U_{3}-U_{2}\right)+c^{(T)}{ }_{13}\left(T_{3}-T_{1}\right)+c_{23}{ }^{(T)}\left(T_{3}-T_{2}\right)= \\
& \operatorname{div}\left[\rho_{3}\left(a_{m}{ }^{(3)} \operatorname{grad}_{3}+\widetilde{a}_{m}{ }^{(3)} \operatorname{grad}_{3}\right)\right]
\end{aligned}
$$

where $c_{23}=a_{23}+b_{23}, \quad{ }_{23}^{(T)}=a_{23}^{(T)}+b_{23}^{(T)}, c_{l k}=a_{l k}+b_{l k}, \quad c_{l k}^{(T)}=a_{l k}^{(T)}+b_{l k}^{(T)}$, $\rho_{1}=m_{1} \rho_{10}, \rho_{2}=m_{2} \rho_{20}, \rho_{3}=m_{3} \rho_{30}, \rho_{10}, \rho_{20}$ and $\rho_{30}$ - true densities of fibres, seeds, and air, respectively. $a_{12}, \quad a_{12}^{T}$ - mass transfer and heat transfer coefficients between fibres and seeds for liquid moisture, $a_{13}, \quad a_{13}^{T}$ - mass transfer and heat transfer coefficients between fibres and air, $a_{23}, \quad a_{23}^{T}$-coefficients of mass exchange and heat exchange between seeds and air (drying agent), $-b_{12}, b_{13}, b_{23}, b_{12}^{(T)}, b_{13}^{(T)}, b_{23}^{(T)}$ - similar coefficients for vaporous moisture, $U_{1}=U_{11}+U_{21}, U_{2}=U_{21}+U_{22}, U_{3}=U_{31}+U_{32}$ - total mass of moisture transfer for the fibre system, seeds and air, respectively, $a_{m}^{(k)}=a_{m 1}^{(k)}+a_{m 2}^{(k)}, \widetilde{a}_{m}^{(k)}=\widetilde{a}_{m 1}^{(k)}+\widetilde{a}_{m 2}^{(k)}$.

\section{SOLVING THE PROBLEMS}

The system of equations (1) - (3) describes the process of mass transfer in raw cotton components under the known law of change in the temperature of the fiber, for which we use Fourier's law. Heat consumption for heating components, as well as heat exchange between components:

$$
\begin{aligned}
& c_{1} \rho_{1} \frac{\partial U_{1}}{\partial}=\operatorname{div}\left(\lambda_{1} \operatorname{grad} T_{1}\right)+r^{(1)} I_{11}-\alpha_{12}\left(T_{1}-T_{2}\right)-\alpha_{13}\left(T_{1}-T_{3}\right) ; \\
& c_{2} \rho_{21} \frac{\partial U_{2}}{\partial}=\operatorname{div}\left(\lambda_{2} \operatorname{grad} T_{2}\right)+r^{(2)} I_{12}+\alpha_{12}\left(T_{1}-T_{2}\right)-\alpha_{23}\left(T_{2}-T_{3}\right) ; \\
& c_{3} \rho_{3} \frac{\partial U_{3}}{\partial}=\operatorname{div}\left(\lambda_{3} \operatorname{grad} T_{2}\right)+r^{(3)} I_{13}+\alpha_{13}\left(T_{1}-T_{3}\right)+\alpha_{23}\left(T_{2}-T_{3}\right),
\end{aligned}
$$


where with $\lambda_{k}$ and $r^{(k)}$ - coefficients of thermal conductivity and specific heat of transformation (for fibre $(\mathrm{k}=1)$, for seeds $(\mathrm{k}=2))$ and air $(\mathrm{k}=3), \alpha_{i j}$ - coefficients of internal heat exchange between fibres and seeds $(i=1, j=2)$, air and fibres $(i=1, j=3)$ and air and seeds $(i=2, j=3)$. The power of the source when transferring vaporous moisture will be equal to $I_{11}=I_{21}$ and is determined from the condition $\frac{\partial U_{21}}{\partial}=0$, which gives

$$
\left.I_{21}=\operatorname{div}\left(\tilde{J}_{21}\right)+\rho_{1}\left[b_{12}\left(U_{1}-U_{2}\right)+b_{13}\left(U_{1}-U_{3}\right)+b_{12}^{(T)}\left(T_{1}-T_{2}\right)\right]+b_{13}^{(T)}\left(T_{1}-T_{3}\right)\right] .
$$

Substituting (1) in equation (4), using the expression (7), we get

$$
\begin{aligned}
& c_{1} \rho_{1} \frac{\partial T_{1}}{\partial t}=\operatorname{div}\left(\lambda_{1} \operatorname{grad} T_{1}\right)+r^{(1)} \operatorname{div}\left[\rho_{1}\left(a_{m 2}^{(1)}\right) \operatorname{grad} U_{1}+\widetilde{a}_{m 2}^{(1)} \operatorname{grad} T_{1}\right]-\alpha_{12}\left(T_{1}-T_{2}\right)- \\
& \alpha_{13}\left(T_{1}-T_{3}\right)-r^{(1)} \rho_{1}\left[b_{12}\left(U_{1}-U_{2}\right)+b_{13}\left(U_{1}-U_{3}\right\}+b_{12}^{(T)}\left(T_{1}-T_{2}\right)+b_{13}^{(T)}\left(T_{1}-T_{3}\right)\right] .
\end{aligned}
$$

Similarly, we have

$$
\begin{aligned}
& c_{2} \rho_{2} \frac{\partial T_{2}}{\partial}=\operatorname{div}\left(\lambda_{2} \operatorname{grad} T_{2}\right)+r^{(2)} \operatorname{div}\left[\rho_{2}\left(a_{m 2}^{(2)}\right) \operatorname{grad} U_{2}+\widetilde{a}_{m 2}^{(2)} \operatorname{grad} T_{2}\right]+\alpha_{12}\left(T_{1}-T_{2}\right)- \\
& \alpha_{23}\left(T_{2}-T_{3}\right) r^{(2)} \rho_{2}\left[b_{12}\left(U_{2}-U_{1}\right)+b_{23}\left(U_{2}-U_{3}\right\}+b_{12}^{(T)}\left(T_{2}-T_{1}\right)+b_{23}^{(T)}\left(T_{2}-T_{3}\right)\right] ; \\
& c_{3} \rho_{3} \frac{\partial T_{3}}{\partial}=\operatorname{div}\left(\lambda_{3} \operatorname{grad} T_{3}\right)+r^{(3)} \operatorname{div}\left[\rho_{3}\left(a_{m 2}^{(3)}\right) \operatorname{grad} U_{3}+\widetilde{a}_{m 2}^{(3)} \operatorname{grad} T_{3}\right]+\alpha_{12}\left(T_{1}-T_{2}\right)+\alpha_{23}\left(T_{2}-T_{3}\right) \\
& r^{(3)} \rho_{3}\left[b_{13}\left(U_{3}-U_{1}\right)+b_{23}\left(U_{3}-U_{2}\right\}+b_{13}^{(T)}\left(T_{3}-T_{1}\right)+b_{23}^{(T)}\left(T_{3}-T_{2}\right)\right] .
\end{aligned}
$$

Equations (1)-(3), (8)-(10) for known densities $\rho_{k}$, heat capacity $c_{k}$ and transfer coefficients $\lambda_{k}, r^{(k)}, a_{m i}^{(k)}, \widetilde{a}_{m i}^{(k)}$, mass transfer coefficients $a_{i k}, b_{i k}$ and heat exchange $a_{i k}^{(T)}, b_{i k}^{(T)}, \alpha_{i k}$ form a closed system for determining the moisture content and temperature of the fiber $\left(U_{1}, T_{1}\right)$, seeds' $\left(U_{3}, T_{3}\right)$.

Introducing the coefficients of the phase transformation of a liquid into steam $\varepsilon_{i k}, \varepsilon_{i}$ and thermogradient coefficients according to $\delta_{i k}, \delta_{i}$ the formulas

$$
\begin{aligned}
& \varepsilon_{12}=\frac{b_{12}}{a_{12}+b_{12}}, \varepsilon_{13}=\frac{b_{13}}{a_{13}+b_{13}}, \varepsilon_{23}=\frac{b_{23}}{a_{23}+b_{23}}, \varepsilon_{1}=\frac{a_{m 2}^{(1)}}{a_{m}^{(1)}}, \varepsilon_{2}=\frac{a_{m 2}^{(2)}}{a_{m}^{(2)}}, \varepsilon_{3}=\frac{a_{m 2}^{(3)}}{a_{m}^{(3)}} ; \\
& \delta_{12}=\frac{c_{12}^{(T)}}{c_{12}}, \delta_{13}=\frac{c_{13}^{(T)}}{c_{13}}, \delta_{23}=\frac{c_{23}^{(T)}}{c_{23}}, \delta_{1}=\frac{\widetilde{a}_{m 2}^{(1)}}{a_{m 2}^{(1)}}, \delta_{2}=\frac{\widetilde{a}_{m 2}^{(2)}}{a_{m 2}^{(2)}}, \delta_{1}=\frac{\widetilde{a}_{m 2}^{(3)}}{a_{m 2}^{(3)}} \text { and considering the }
\end{aligned}
$$

one-dimensional transfer case (flat case $n=0$, cylindrical symmetry $n=1$ and the case of spherical symmetry $n=2)$ give the equation (1)-(3), (8)-(10) to mind

$$
\rho_{i} \frac{\partial U_{i}}{\partial t}=\left(\frac{\partial}{\partial x}+\frac{n}{x}\right)\left[a_{m}^{(i)} \rho_{i}\left(\frac{\partial U_{i}}{\partial x}+\delta_{i} \frac{\partial T_{i}}{\partial x}\right)\right]-\rho_{i} \sum_{k=l}^{3} c_{i k}\left[U_{i}-U_{k}+\delta_{i k}\left(T_{i}-T_{k}\right)\right]
$$




$$
\begin{aligned}
& c_{i} \rho_{i} \frac{\partial T_{i}}{\partial t}=\left(\frac{\partial}{\partial x}+\frac{n}{x}\right)\left(\lambda_{i} \frac{\partial T}{\partial x}\right)+r^{(i)}\left(\frac{\partial}{\partial x}+\frac{n}{x}\right)\left[\varepsilon_{i} a_{m}^{(i)} \rho_{i}\left(\frac{\partial U_{i}}{\partial x}+\delta_{i} \frac{\partial T_{i}}{\partial x}\right)\right]- \\
& \left.-\sum_{k=1}^{3} \alpha_{i k}\left(T_{i}-T_{k}\right)-r^{(i)} \rho_{i} \sum_{k=1}^{3} c_{i k} \varepsilon_{i k}\left[U_{i}-U_{k}\right)+\delta_{i k}\left(T_{i}-T_{k}\right)\right]
\end{aligned}
$$

where $\mathrm{i}=1,2,3, \mathrm{c}_{21}=\mathrm{c}_{12}, \mathrm{c}_{32}=\mathrm{c}_{23}, \varepsilon_{32}=\varepsilon_{23}, \alpha_{21}=\alpha_{21}, \alpha_{32}=\alpha_{23}$.

To integrate equations (11) and (12), the following initial, boundary, and symmetry conditions must be met:

$U_{i}=U_{i 0}=$ const at $\mathrm{t}=0$

$-\lambda_{i c} \frac{\partial T}{\partial x}+a_{i c}\left(T_{c}-T_{i}\right)-\left(1-\varepsilon_{i c}\right) \rho_{i} \eta_{i c} r_{c}^{(i)}\left(U_{i}-U_{c}\right)=0$ at $\mathrm{x}=\mathrm{R}$,

$a_{m c}^{(i)}+\delta_{i c} \frac{\partial T_{i}}{\partial x}+\eta_{i c}\left(U_{i}-U_{c}\right)=0$ at $\mathrm{x}=\mathrm{R}, \frac{\partial U_{i}}{\partial x}=0,-\frac{\partial T_{i}}{\partial x}=0$ at $\mathrm{x}=0$,

where $\lambda_{i c},-\rho_{i c},-a_{m c}^{(i)},-\delta_{i c},-\varepsilon_{i c-}$ - boundary values of thermal conductivity, density, substance diffusion coefficient, thermogradient coefficient and phase transformation criterion for the i-th phase, $\alpha_{i c}, \eta_{i c}$ coefficients of heat and mass transfer of the i-th phase with the external environment, $\mathrm{T}_{\mathrm{C}}$ and $\mathrm{U}_{\mathrm{C}}$-values of temperature and humidity of the external environment.

For a moving medium, the time derivative operator $\frac{\partial}{\partial t}$ replaced by the full derivative operator using the formula $\frac{d}{d t}=\frac{\partial}{\partial}+v \frac{\partial}{\partial x}$, where $v_{i}$ - is the velocity of transport of medium particles. Then the transport equations (11) and (12) for a moving medium can be written as:

$$
\begin{aligned}
& \rho_{i}\left(\frac{\partial U_{i}}{\partial}+v_{i} \frac{\partial U_{i}}{\partial x}\right)=\left(\frac{\partial}{\partial x}+\frac{n}{x}\right)\left[a_{m}^{(i)} \rho_{i}\left(\frac{\partial U_{i}}{\partial x}+\delta_{i} \frac{\partial T_{i}}{\partial x}\right)\right]-\rho_{i} \sum_{k=1}^{3} c_{i k}\left[U_{i}-U_{k}+\delta_{i k}\left(T_{i}-T_{k}\right)\right] \\
& c_{i} \rho_{i}\left(\frac{\partial T_{i}}{\partial t}+v_{i} \frac{\partial T_{i}}{\partial x}\right)=\left(\frac{\partial}{\partial x}+\frac{n}{x}\right)\left(\lambda_{i} \frac{\partial T_{i}}{\partial x}\right)+r^{(i)}\left(\frac{\partial}{\partial x}+\frac{n}{x}\right)\left[\varepsilon_{i} a_{m}^{(i)} \rho_{i}\left(\frac{\partial U_{i}}{\partial x}+\delta_{i} \frac{\partial T_{i}}{\partial x}\right)\right]- \\
& \left.\sum_{k=1}^{3} \alpha_{i k}\left(T_{i}-T_{k}\right)-r^{(i)} \rho_{i} \sum_{k=1}^{3} c_{i k} \varepsilon_{i k}\left[U_{i}-U_{k}\right)+\delta_{i k}\left(T_{i}-T_{k}\right)\right],
\end{aligned}
$$

where $v_{i}$ is the speed of movement of fibres $(\mathrm{i}=1)$, seeds $(\mathrm{i}=2)$ and air $(\mathrm{i}=3)$

In the case of a one-dimensional $(n=0)$ stationary transfer mode $\left(\frac{\partial U_{i}}{\partial}=0, \frac{\partial U_{i}}{\partial t}=0\right)$ at constant values of travel speeds $v_{i}=v_{i 0}=$ const, thermal and mass transfer parameters of raw cotton components [11-17].

$$
\begin{aligned}
& \rho_{i}=\rho_{i 0}=\text { const }, a_{m}^{(i)}=a_{m^{0}}^{(i)}=\text { const }, \lambda_{i}=\lambda_{i 0}=\text { const }, \delta_{i}=\delta_{i 0}=\text { const }, \varepsilon_{i}=\varepsilon_{i 0}=\text { const }, \\
& r^{(i)}=r_{0}^{(i)}=\text { const }, c_{i}=c_{i 0}=\text { const have }
\end{aligned}
$$




$$
\begin{aligned}
& \frac{d \bar{U}_{i}}{d \xi}=\gamma^{(i)} L u_{i}\left(\frac{d^{2} \bar{U}_{i}}{d \xi^{2}}+\rho_{i} \frac{d^{2} \bar{T}_{i}}{d \xi^{2}}\right) \quad-\sum_{k=1}^{3} \lambda_{i k}\left[\bar{U}_{i}-\bar{U}_{k}+\rho_{i k}\left(\bar{T}_{i}-\bar{T}_{k}\right)\right] \\
& \frac{d \bar{T}_{i}}{d \xi}=\gamma^{(i)}\left(K^{(i)}{ }_{11}\left(\frac{d^{2} \bar{T}_{i}}{d \xi^{2}}+\rho_{i} \frac{d^{2} \bar{T}_{i}}{d \xi^{2}}\right)-\sum_{k=1}^{3} \theta_{i k}\left[\bar{U}_{i}-\bar{U}_{k}-\sum_{k=1}^{3} \sigma_{i k}\left(\bar{T}_{i}-\bar{T}_{k}\right),\right.\right.
\end{aligned}
$$

where $\bar{T}=\frac{T}{T_{0}}, \bar{U}=\frac{U}{U_{0}}, \gamma^{(i)}=\frac{a_{i}}{L v_{i 0}}, L u_{i}=\frac{a^{(i)}{ }_{m 0}}{a_{i}}, \rho_{n i}=\frac{\delta_{i 0} T_{0}}{U_{0}}, \lambda_{i k}=\frac{c_{i k} L^{2}}{v_{i 0}}, \rho_{i k}=\frac{\delta_{i k} T_{0}}{U_{0}}$, $K_{11}^{(i)}=1+\varepsilon_{i 0} K_{0 i} \rho_{n i} L u_{i}, K_{12}^{(i)}=\varepsilon_{i 0} K_{0 i} L u_{i}, K_{0 i}=\frac{r^{(i)}{ }_{0} U_{0}}{c_{i 0} T_{0}}, \theta_{i k}=\lambda_{i k} K_{0 i} \varepsilon_{i k}$, $\sigma_{i k}=\beta_{i k}+\theta_{i k} \rho_{i k}, \beta_{i k}=\frac{a_{i k} L^{2}}{\lambda_{i 0} a_{i}}, a_{i}=\frac{\lambda_{i 0}}{c_{i 0} \rho_{i 0}}, T_{0} \mathrm{i}-U_{0}$ initial (equilibrium) values of temperature and moisture of any component (for example, air) of raw cotton. The system in Eq. (14) and (15) are integrated under the following boundary conditions

$$
\begin{aligned}
& \bar{T}_{i}=\bar{T}_{n i}, \bar{U}_{i}=\bar{U}_{n i} \text { by } \xi=0, \\
& -\frac{\partial \bar{T}_{i}}{\partial \xi}+\beta_{i c}\left(\bar{T}_{c}-\bar{T}_{i}\right)-\left(1-\varepsilon_{i c}\right) \mu_{i c}\left(\bar{U}_{i}-\bar{U}_{c}\right)=0 \text { at } \xi=1, \\
& \frac{\partial \bar{U}_{i}}{\partial \xi}+\rho_{n i} \frac{\partial \bar{T}_{i}}{\partial \xi}+v_{i c}\left(\bar{U}_{i}-\bar{U}_{c}\right)=0 \text { at } \xi=1,
\end{aligned}
$$

where $\xi=\frac{x}{L}, \beta_{i c}=\frac{a_{i c} L}{\lambda_{i 0}}, \mu_{i c}=\frac{\eta_{i c} r^{(i)}{ }_{0} U_{0} L}{c_{i 0} T_{0} a_{i}}, v_{i c}=\frac{\eta_{i c} U_{0} L}{a_{m 0}(0)}, \bar{T}_{n i}=\frac{T_{n i}}{T_{0}}, \bar{U}_{n i}=\frac{U_{n i}}{U_{0}}$,

$\bar{U}_{c}=\frac{U_{c}}{U_{0}} T_{n i}$ and $U_{n i}$ - set values of temperature $i=$ and moisture of the o-th component in the cross- section $x=0$.

As an example, consider the process of drying raw cotton in a dryer in a drum, where the fibres and seeds move at the same speed $v_{10}=v_{20}=v_{0}$ and equal in size $v_{0}=q v_{30}$. The research is carried out using the following initial data, corresponding to the properties of the real properties of raw cotton and the parameters of the dryer [6]:

$$
\begin{aligned}
& T_{0}=20, \quad U_{0}=10, \quad T_{n 1}=20, \quad T_{n 2}=20, \quad T_{n 3}=150, \quad U_{n 1}=20, U_{n 2}=20, U_{n 3}=10, \\
& p_{12}=p_{13}=p_{23}=0.1, \quad \varepsilon_{12}=\varepsilon_{13}=\varepsilon_{0.5}, \quad K_{01}=0, \quad K_{02}=K_{03}=1
\end{aligned}
$$

The maximum values of seed moisture are $20 \%$ at the beginning of the drum, i.e. before drying, and at the end, i.e. at the end of drying $\approx 17.5 \%$. The pattern of removing moisture from the fibre differs significantly from similar patterns corresponding to seeds. At the beginning and end of the drying process the fibre humidity has the following limits $20 \%$ и $\approx 12 \%$.

Based on equation. (14) and (15), a computational model of the cotton drying process has been developed (Fig. 1), which characterizes the dependence of changing parameters. Simulation experiments were conducted to study the properties of these dependencies. The 
calculations were performed in the MATLAB system. The transition process graphs are shown in Fig. 2.

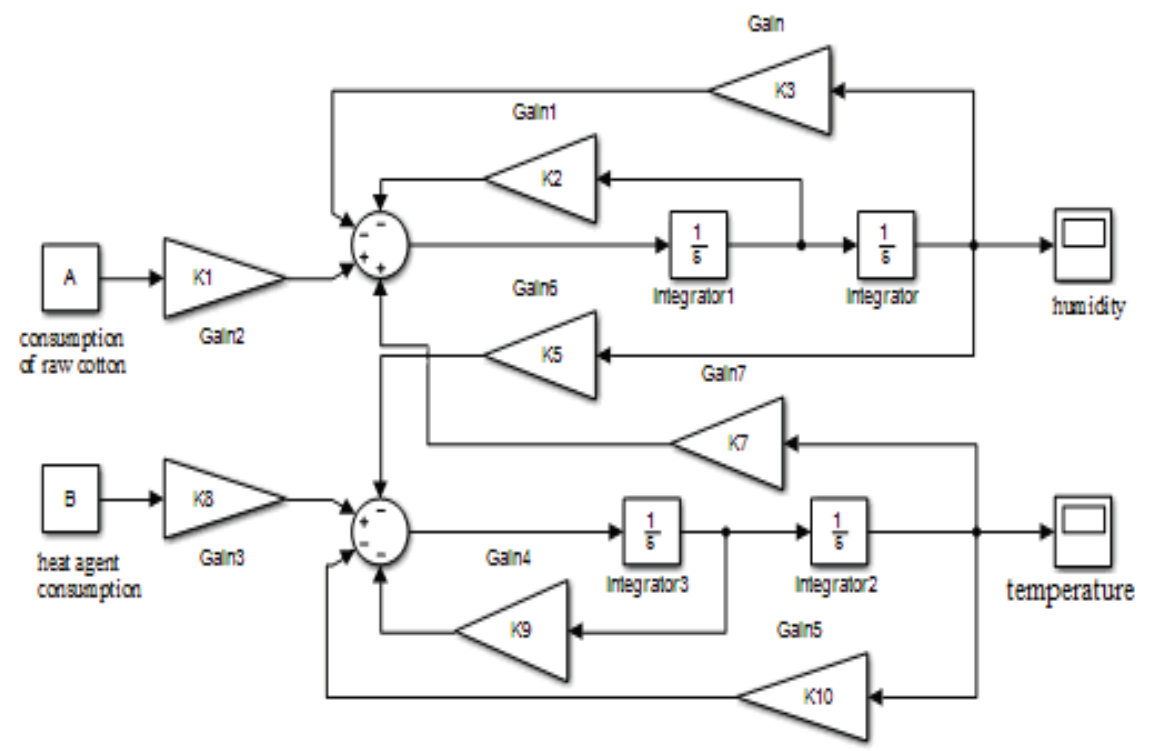

Fig.1: Modelling scheme of static mode of raw cotton drying process (with distributed parameters).

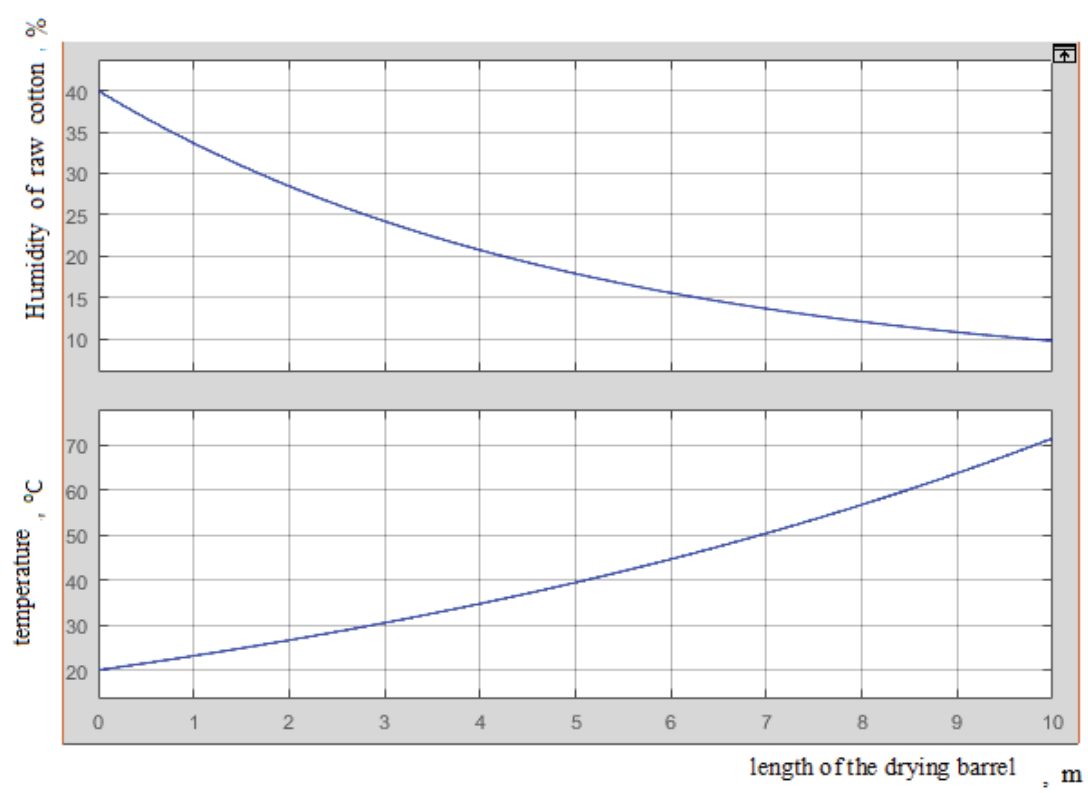

Fig. 2: Graphs of the transition process.

To calculate the processes in the computational model, the following are entered:

$$
\begin{gathered}
k_{1}=L \cdot x_{1} \cdot \gamma \quad, \quad k_{2}=k_{1} \rho \quad, \quad k_{3}=\theta, \quad k_{4}=\rho, \\
k_{5}=\gamma \cdot k, \quad k_{6}=k_{5} \rho, \quad k_{7}=\theta, \quad k_{8}=\delta
\end{gathered}
$$

Comparing the results, we conclude that the seeds at the exit of the drum have a humidity of $17,5 \%$, and fiber $-12 \%$. The moisture content of the seed is $2.5 \%$, and that of the fibre 
is $8 \%$, which means that to intensify the drying of raw cotton seeds, it is necessary to improve the access of heated air to their surface.

It follows that in order to obtain high-quality fibre and seeds, it is proposed to maintain the seed temperature at the exit of the drum at about $50 \%$ of the input temperature.

\section{CONCLUSION}

A dynamic mathematical model of the drying process is constructed, which determines the regularities of changes in the moisture content of fibre and seeds, which depend not only on the humidity of the original cotton, but also on the consumption of the supplied heat agent. Verification of the adequacy of the developed model is carried out by comparing real data with the result of simulation modelling.

Thus, a mathematical model of the raw cotton drying process is obtained, which allows us to determine the dynamic properties of the control system and choose rational modes of operation of aggregates with optimal control of the entire process and increase production productivity without compromising the natural properties of cotton fibres and seeds.

\section{ACKNOWLEDGEMENTS}

I thank you for giving me such an opportunity to work under your IIUM engineering journal. Huge thanks to my supervisor Dr I.H. Sidikov for providing me great insight and knowledge, for his continuous encouragement and for providing me with many of his valuable time. I would also like to thank my friends Muhiddin Atajonov, and others who have given me moral support and stayed with me at the university for many days. Without their support, I could not have spent so much time and effort on my article.

Finally, I thank goes to the Tashkent State Technical University, Department of "Information Processing and Control Systems" staffs for their support and taking me to the next level in my studies.

\section{REFERENCES}

[1] Cotton: World Statistics. Bulletin of the International Cotton Advisory Committee, NY, November 2015.http://www.ICAC.org., http://www.USDA.gov.

[2] Parpiev A.P, Mamatov A.Z, Usmankulov A.K. (2000) Maximum permissible temperatures in the drum dryer. IzvestiyaVuzov, 1:35-36.

[3] Usmankulov A. (2002) Improving the efficiency of the drying process of raw cotton in a drum dryer, Diss. for the degree of candidate of technical Sciences Tashkent; pp128.

[4] Mamatov A.Z. (1995) Modeling of raw cotton drying technology to improve the quality of fiber, Diss. On competition of a scientific degree. doctor of technical Sciences Tashkent; pp 248.

[5] Siddikov I.X, Umurzakova D.M. (2019) Features of automatic control of technological parameters of water level in the drum steam boilers, Journal of Southwest Jiaotong University,54(3):1-10. DOI:10.35741/issn.0258-2724.54.3.1.

[6] Siddikov I.X, Umurzakova D.M. (2019) Mathematical Modeling of Transient Processes of the Automatic Control System of Water Level in the Steam Generator, Universal Journal of Mechanical Engineering, 7(4):139-146. DOI:10.13189/ujme.2019.070401.

[7] Siddikov I.X, Umurzakova D.M. (2019) Adaptive neuron-fuzzy regulating system of the temperature mode of the drum boiler. International Journal of Advanced Research in Science, Engineering and Technology, 6(1) 7869-7872. (2019).

[8] Siddikov I.X, Umurzakova D.M, Bakhrieva H.A. (2020) Adaptive system of fuzzy-logical regulation by temperature mode of a drum boiler // IIUM Engineering Journal 21(1):182-192. https://doi.org/10.31436/iiumej v 2lil.1220. 
[9] Yunusova S.T. (2013) On the formalization of the optimization criterion of the cleaning process of raw cotton to Tashkent State Technical University. Bulletin. 3:35-40.

[10] Sidikov I.H, Atajonov M.O, Yunusova S.T, Nashvandova. G.M. (2020) Adaptive analytical control of technological parameters based on the probability method of oil refining installations, European Science Review, Scientific Journal, 1(2):78-83 https://doi.org/10.29013/ESR-20-1.2-78-83.

[11] Kholmatov D. A, Yunusova S. T. Setmetov N. U, Khuzhanazarov U. O. (2014) Information and algorithmic technological monitoring system algorithmic processes processing of raw cotton., WCIS-Eighth World Conference on Intelligent Systems for Industrial Automatic. Toshkent .261-264

[12] Siddiqov IH, Yunusova ST, Izmailova NR. (2018) Algorithm for optimization of the membership function of the fuzzy control model on the basis of the probabilistic approach. WCIS - 2018, Tenth World Conference on Intelligent Systems for Industrial Automation October 25-26, Tashkent, Uzbekistan, 251-254

[13] Yunusova ST. (2019) Fuzzy logic model of temperature control of a drying unit based on a probabilistic approach. Collection of reports of the Republican scientific and practical conference on "Innovations in the development of information and communication technologies" April 15-17.

[14] Kholmatov DA, Yunusova ST, Setmetov NU, Khuzhanazarov UO. (2019) Software tool monitoring process of processing raw cotton. International Journal of Advanced Research in Science, Engineering and Technology, 6(2): 8140-8143.

[15] Igamberdiyev H.Z, Yusupbekov A.N, Zaripov O.O,Sevinov J.U. (2017) Algorithms of adaptive identification of uncertain operated objects in dynamical models. Procedia Computer Science.120. 854-861. DOI: 10.1016/j.procs.2017.11.318.

[16] Sidikov I.H, Atajonov M.O, Atajonova S.B. (2019) Fuzzy-Situational Diagnostics of Technological Safety of Petrochemical Plants, 4(7):182-186. DOI:10.33564/IJEAST. 2019.v04i07.030 